\title{
Application of the Spores of the Entomopathogenic Fungus Lecanicillium Muscarium for Control of Adelgids on Conifers in the Peter the Great Botanical Garden
}

\section{Elizaveta Varfolomeeva1, Galina Mitina² and Anna Choglokova²}

${ }^{1}$ Komarov Botanical Institute of the Russian Academy of Sciences, 197376 St. Petersburg, Russia 2 All-Russian Institute of Plant Protection, 196608 St. Petersburg, Russia

\section{ORCID}

Elizaveta Varfolomeeva; 0000-0002-4095-6918

Abstract. This article discusses the possibility of using the entomopathogenic fungus Lecanicillium muscarium R. Zare \& W. Gams (Ascomycota: Hypocreales) against the fir adelgid Adelges pectinatae pectinatae (Cholodkovsky, 1888) and Siberian cedar adelgid Pineus cembrae (Cholodkovsky, 1888) on the Siberian fir Abies sibirica Ledeb.

Corresponding Author: Elizaveta Varfolomeeva; email:

varfolomeeva.elizaveta@list.ru

Dates

Published 13 January 2022

Publishing services provided by Knowledge E

(c) Elizaveta Varfolomeeva et

al. This article is distributed

under the terms of the

which permits unrestricted use and redistribution provided that the original author and source are credited.

Selection and Peer-review under the responsibility of the 8th Scientific and Practical Conference Conference Committee.

\section{G OPEN ACCESS} and pines Pinus sibirica Du Tour and Pinus banksiana Lamb. The blastospores of the entomopathogenic fungus L. muscarium strain G-033 VIZR, in the concentration of $5 \times 10^{7}$ spores $/ \mathrm{ml}$, showed a high efficiency on both of the species of adelgid. On the 17 th day, the mortality of $P$. cembrae was $73 \%$ on $P$. sibirica and $61 \%$ on $P$. banksiana, and the mortality of the species $A$. pectinatae pectinatae on $A$. sibirica was $74 \%$. The effect of the spore application had a prolonged effect over the next month on all treated trees.

Keywords: entomopathogenic fungi, Lecanicillium muscarium, adelgid, conifers

\section{Introduction}

In the recent decades, the pests of coniferous called adelgid or hermes (Hemiptera: Adelgidae) are usually found not only in nature but also in parks, plantings, green areas of towns and cities. They are the carriers of coniferous bacteriosis. Trees weakened by adelgid are affected by the bark beetle more often and become susceptible to phytopathogenic fungi. Outbreaks of adelgid epizootics are found throughout Russia. About 65 species of adelgid are well-known. They are all native to the northern hemisphere, although someones have been discovered in the southern hemisphere as invasive species.

Focality and sporadic distribution of adelgid is its characteristic environmental feature. The reasons for the formation of such local populations of adelgid are: the using of planting material affected by adelgid; limited ability of non-migratory species to active 
resettling, large territorial fragmentation of parkland, and inside them - isolation of coniferous (in flower bed and soliter) by deciduous trees, the population is confined to the focus of mass reproduction of pests (tree, biotope), which is often so pronounced that it is sometimes created huge microcenters even inside the crown of centuries-old trees [1].

Another feature of the adelgid ecology is the photophilousness of winged female settlers, immigrants and aphids. As a result of this, the number of galls in the crowns of spruces is always much larger on the periphery than inside; peripheral trees are more heavily populated in the plantations; in dense stands of alley type, the open parts of the crowns are primarily inhabited; the most populated trees are those ones that grow in dry lit places; in the shaded areas of the plantations, only foci of late spruce adelgid occur during planting with infected trees [2].

The full cycle of adelgid development lasts two years, sometimes one year, and it is characterized by migration to the intermediate hosts - other coniferous species. A cyclic change of nutrition is due to the appearance of various biological forms of the species and a periodic change in the forms of reproduction - heterogony. Adelgid gives 2-3 generations per year [3]. According to long-term data of Firsov G.A. the climate warming contributes to an increase in the number of adelgid generations [4].

Regular entomo-phytopathological examinations of conifers to identify adelgid were started in 1980 in the Peter the Great Botanical Garden. Adelgid is currently distributed throughout the garden, both in the older, regular part of the Park-Arboretum, and in the landscape part. Brown fir adelgid Adelges pectinatae pectinatae (Cholodkovsky, 1888) and Siberian cedar adelgid Pineus cembrae (Cholodkovsky, 1888) are found on Siberian fir Abies sibirica Ledeb. and Pinus sibirica Du Tour and Pinus banksiana Lamb. pines [5].

In the Botanical Garden of Peter the Great, a complex of agrotechnical, mechanical and chemical measures is used to protect from adelgid. To increase the resistance of coniferous plants, they are planted in loose soil, acid peat. After planting, in the first year the soil and the tree crown are watered carefully, as well as the soil in the nearstem circle is mulched with a thick layer of pine bark. To stimulate the root system, root gum 10 grams / 10 litres, Radiopharm $0.25 \%$ and root dressings with potassium humate $0.2 \%$ are used. If galls are detected on a growing plant, the shoots are trimmed and destroyed before the development of the larvaes are completed (no later than June). For several years, the following preparations were applied: Actara $0.06 \%$, Confidor extra $0.04 \%$, Clipper $0.1 \%$. Biological effectiveness ranged from $70 \%$ to $98 \%$. In view of the 
peculiarities of the development of the pest, the treatments were carried out according to the system developed by us, alternating preparations:

1. Against wintering larvae in the spring (April-May).

2. Against larvae emerging from eggs (end of May-June).

3. When nymphs and winged individuals from galls appear (August).

4. Against wintering larvae (September-October).

Entomophages have been successfully used to control adelgid abroad, especially in the USA, Canada, and China. Various coccenillids (Coleoptera: Coccinellidae), silver flies (Diptera: Chamaemyiidae), and predatory ground beetles (Coleoptera: Derodontidae) were tested as promising predators for protecting conifers [6]. To control the adelgid Adelges tsugae (Annand, 1928), that was brought previously to the United States, coccinellids, sirfides, gall midges, lacewings and predatory mites were successfully introduced from Japan [7].

The search for microbiological agents to control adelgid in the United States has been lasting for about 25 years. Entomopathogenic fungi from the genera Beauveria, Paecilomyces, Lecanicillium and Myriangium were identified among the species causing epizootics of adelgid [8]. Entomopathogens Lecanicillium lecanii, Isaria farinosa, Beauveria bassiana and Fusarium spp. were isolated from the adelgid $A$. tsugae, causing the death of coniferous forests, in particular the species Tsuga canadensis (L.) in China, and Tsuga caroliniana Englem in USA. Several strains belonging to the first three species showed a high pathogenicity in the laboratory [9]. In our country, the search is also underway for the biological agents against adelgid, special attention was paid to the entomopathogenic viruses [10]. Entomopathogenic fungi have several advantages for the control of adelgid, as they are able to overcome the protective shield of adelgid, fungal spores easily spread with air flows and can remain viable for quite a long time. However, until now, the chemical insecticides Aktara and Decis remain the main means of protection of conifers in the urban environment from adelgid [11].

To reduce the chemical pressure that negatively affects the ecology of agrocenosis, entomopathogenic fungi have been successfully tested in greenhouses of the Botanical Garden for protection against sucking pests, and their effectiveness has been obtained at low temperatures [12].

These results allowed us to proceed to the tests in the open ground and evaluate the effectiveness of entomopathogenic fungi against adelgid on conifers.

For this purpose, fungus Lecanicillium muscarium R. Zare \& W. Gams (Ascomycota: Hypocreales), which is a natural pathogen of the sucking insects from the order 
Hemiptera was chosen. Numerous microbiological preparations based on the spores of this fungus have been developed [13].

In the summer of 2019, in the Peter the Great Botanical Garden of Peter the Great Botanical Institute RAS (BIN), a focal lesion of conifers by adelgid was recorded. At the base of the needles of fir and pine needles, an accumulation of white fluffy bloom was observed. In these foci, spores of the fungus $L$. muscarium were applied.

\section{Methods}

To obtain a laboratory sample of a biological product based on blastospores of the entomopathogenic fungus L. muscarium, strain G-033 VIZR deposited in the Collection of the All-Russian Institute of Plant Protection -VIZR (WFCC WDCM №760) was used. The strain is proved to be highly promising for control sucking insects (aphids and greenhouse whiteflies) and ticks [14, 15].

Strain G-033 VIZR was cultivated on liquid glucose-peptone-yeast nutrient medium in $750 \mathrm{~mL}$ Erlenmeyer flasks at a temperature of $26^{\circ} \mathrm{C}$ with constant shaking (165 rpm) for 4 days. The resulting culture suspension was homogenized and adjusted to a concentration of $5 \times 10^{7}$ spores $/ \mathrm{ml}$. Polysorbate $(0.01 \%$ in working solution) was added as an adhesive to improve adhesion of fungus spores on the galls.

Fresh spore suspension was used to treat infected plants of three species: Siberian fir A. sibirica, and pines $P$. sibirica and $P$. banksiana. The average age of the trees was 10-12 years. Application was carried out at a height of 1-1.5 $\mathrm{m}$ from the ground on the lesions. The number of pests was taken into account before treatment and weekly for a month by the number of fluffy galls. Actara insecticide on pine and fir was used as a chemical standard in the recommended concentration. In total, 2 specimens of cedar pine and Banks pine, 4 specimens of Siberian fir were treated. Statistical analysis was performed using SigmaPlot version 12.5 Systat Software. The data were analyzed by oneway ANOVA with the Tukey's test for mean separation ( $\alpha=0.05$ ) (ANOVA). Effectiveness of treatments was estimated with the Henderson-Tilton's formula.

\section{Results}

On untreated plants, the number of pests was about 20 colonies of adelgid on one bunch of pine needles and approximately 10 colonies on one fir sprout about $5 \mathrm{~cm}$ of length. It did not change significantly during the observations, which may be due to the peculiarities of the adelgid life cycle. 
TABLE 1: Biological effectiveness of blastospores of Lecanicillium muscarium against adelgid Pineus cembrae on Pinus sibirica and Pinus banksiana.

\begin{tabular}{|c|c|c|c|c|c|c|}
\hline \multirow{2}{*}{$\begin{array}{l}\text { Treatment, } \\
\text { concentration }\end{array}$} & \multirow{2}{*}{$\begin{array}{l}\text { The number } \\
\text { of adelgid } \\
\text { coloneis } \\
\text { before } \\
\text { treatment }\end{array}$} & \multicolumn{5}{|c|}{ Adelgid mortality on the day after treatment, \% } \\
\hline & & 7 & 10 & 17 & 24 & 31 \\
\hline \multicolumn{7}{|c|}{ G-033 VIZR on Pinus sibirica } \\
\hline $\begin{array}{l}1 \text { specimen } 2 \\
\text { specimen }\end{array}$ & $\begin{array}{l}23,9 \pm 1,9^{c} \\
11,2 \pm 1,4^{a}\end{array}$ & $\begin{array}{l}17,7 \pm 1,4^{a} \\
24,9 \pm 3,7^{b}\end{array}$ & $\begin{array}{l}32,9 \pm 2,6^{a} \\
42,1 \pm 3,7^{b}\end{array}$ & $\begin{array}{l}54,4 \pm 4,1^{a} \\
90,8 \pm 5,0^{b}\end{array}$ & $\begin{array}{l}85,1 \pm 4,0^{b} \\
99,3 \pm 0,7^{c}\end{array}$ & $\begin{array}{l}95,5 \pm 2,2^{a} \\
100,0 \pm 0,0^{a}\end{array}$ \\
\hline \multicolumn{7}{|c|}{ G-033 VIZR on Pinus banksiana } \\
\hline $\begin{array}{l}1 \text { specimen } 2 \\
\text { specimen }\end{array}$ & $\begin{array}{l}10,2 \pm 0,9^{a} \\
7,0 \pm 0,9^{a}\end{array}$ & $\begin{array}{l}16,7 \pm 3,9^{a} \\
39,9 \pm 8,3^{c}\end{array}$ & $\begin{array}{l}36,3 \pm 4,6^{a} \\
52,2 \pm 7,7^{b}\end{array}$ & $\begin{array}{l}56,2 \pm 3,3^{a} \\
66,3 \pm 7,2^{a}\end{array}$ & $\begin{array}{l}74,7 \pm 4,1^{a} \\
86,3 \pm 4,4^{b}\end{array}$ & $\begin{array}{l}92,4 \pm 2,4^{a} \\
93,3 \pm 3,7^{a}\end{array}$ \\
\hline Aktara $0,06 \%$ & $16,6 \pm 2,1^{b}$ & $49,6 \pm 2,2^{c}$ & $95,4 \pm 1,6^{c}$ & $99,2 \pm 0,6^{b}$ & $100,0 \pm 0,0^{c}$ & $100,0 \pm 0,0^{a}$ \\
\hline
\end{tabular}

TABLE 2: Biological effectiveness of blastospores of Lecanicillium muscarium against adelgid Adelges pectinatae pectinatae on Abies sibirica

\begin{tabular}{|c|c|c|c|c|c|c|}
\hline \multirow{2}{*}{$\begin{array}{l}\text { Treatment, } \\
\text { concentration }\end{array}$} & \multirow{2}{*}{$\begin{array}{l}\text { The number } \\
\text { of adelgid } \\
\text { coloneis } \\
\text { before } \\
\text { treatment }\end{array}$} & \multicolumn{5}{|c|}{ Adelgid mortality on the day after treatment, $\%$} \\
\hline & & 7 & 10 & 17 & 24 & 31 \\
\hline \multicolumn{7}{|c|}{ G-033 VIZR on Abies sibirica } \\
\hline 1234 & $\begin{array}{l}10,6 \pm 1,3^{a} \\
17,4 \pm 1,7^{b} \\
12,6 \pm 1,6^{a} \\
12,8 \pm 1,1^{a}\end{array}$ & $\begin{array}{l}24,8 \pm 4,8^{a} \\
15,5 \pm 2,1^{a} \\
23,3 \pm 2,6^{a} \\
19,7 \pm 2,7^{a}\end{array}$ & $\begin{array}{l}46,2 \pm 8,2^{b} \\
25,8 \pm 3,0^{a} \\
38,0 \pm 2,4^{b} \\
35,6 \pm 3,8^{b}\end{array}$ & $\begin{array}{l}81,4 \pm 6,5^{b} \\
58,6 \pm 3,6^{a} \\
85,2 \pm 5,6^{b} \\
71,3 \pm 3,2^{b}\end{array}$ & $\begin{array}{l}98,2 \pm 1,4^{b} \\
85,0 \pm 4,2^{a} \\
97,0 \pm 2,5^{b} \\
94,1 \pm 2,9^{b}\end{array}$ & $\begin{array}{l}100,0 \pm 0,0^{a} \\
96,8 \pm 1,8^{a} \\
100,0 \pm 0,0^{a} \\
97,3 \pm 1,4^{a}\end{array}$ \\
\hline Aktara $0,06 \%$ & $10,2 \pm 0,9^{a}$ & $52,0 \pm 5,9^{b}$ & $99,2 \pm 0,8^{c}$ & $99,2 \pm 0,8^{c}$ & $100,0 \pm 0,0^{b}$ & $100,0 \pm 0,0^{a}$ \\
\hline
\end{tabular}

The efficiency of the chemical standard reached $95-99 \%$ already on the 10th day, which was twice as high as efficiency of the microbial preparation on the same day (Tables 1, 2).

The increase in the effectiveness of the spore preparation occurred gradually, and on the 17th day the mortality of both species of adelgid on the separate trees was comparable with the effect of the standard. On the 17th day, the average mortality of adelgid of the species $P$. cembrae on $P$. sibirica and $P$. banksiana was $72.6 \%$ and $61.2 \%$, respectively, and mortality of the species $A$. pectinatae pectinatae on $A$. sibirica was 74\%. In relation to aphids (Aphididae), strain G-033 VIZR caused 95-100\% mortality already on the 7-10 days after application. 


\section{Conclusion}

Slower death of adelgid is associated with overcoming the protective cover of the host, its subsequent colonization and infection of adelgid. As a result of sporulation of the fungus, it continued to spread in the pest foci and mortality increased up to $100 \%$ a month after application. The ability of the L. muscarium fungus to cause adelgid mycosis has been proved by isolating strain G-033 VIZR from a colony of adelgid on pine needles. The effect of the spore application was maintained over the next month on all treated trees. Thus, the biopreparation based on the blastospores of the entomopathogenic fungus $L$. muscarium strain G-033 VIZR showed a high efficiency and a prolonged effect on the adelgids of two species: $A$. pectinatae pectinatae and $P$. cembrae. This is the first report of the trials of entomopathogenic fungi on the conifers in the Botanical Garden of Peter the Great. The experience can be used in different botanical gardens and parks to protect conifers from adelgid.

\section{Funding}

The work was carried out as part of a state assignment on the planned topic "Collections of living plants of the Komarov Botanical Institute (history, current state, prospects of use) ", number AAAA-A18-118032890141-4.

\section{References}

[1] Bukhlova EE, Conusova OL, Lukyanova MG. Siberian cedar hermes (Pineus cembrae ?hol., Hemiptera, Adelgidae) in artificial plantations of Siberian cedar in the city of Tomsk. Presented at: All-Russian Conference: Ecology and Environmental Management; 2017; 20-24 September, Tomsk: TSU.

[2] van Driesche RG, Simberloff D, Blossey B et al. Integrating biological control into conservation practice. Van Driesche RG, Simberloff D, Blossey B et al, editors. Benefit-risk assessment of biological control in wildlands.New Jersey, John Wiley \& Sons Limited 2016.

[3] Favret C, Havill NP, Miller GL et al. (2015). Catalog of the adelgids of the world (Hemiptera, Adelgidae). ZooKeys. 2015;534(11):35-54.

[4] Firsov GA, Fadeeva IV. CLIMATE CHANGE AND POSSIBLE CHANGES IN THE RANGE OF WOODY PLANTS IN ST. PETERSBURG Bulletin of the Main Botanical Garden. 2020;1:57-63. 
[5] Firsov GA, Varfolomeeva EA, Khmarik AG. CONIFEROUS PLANTS INVOLVED BY THE FAMILY HERMES (ADELGIDAE) AND MEASURES TO CONTROL ITS REPRESENTATIVES IN ST. PETERSBURG Bulletin of the Udmurt University. 2017;4:473-480.

[6] McCarty EP, Addesso KM. Hemlock woolly adelgid (Hemiptera: Adelgidae) management in forest, landscape, and nursery production. Journal of Insect Science. 2019;19(2). 031-031 doi.org/ 10.1093/jisesa/iez031.

[7] Letheren A, Hill S, Salie J et al. A little bug with a big bite: Impact of hemlock woolly adelgid infestations on forest ecosystems in the eastern USA and potential control strategies. International Journal of Environmental Research and Public Health. 2017;14(4):438-438. doi:10.3390/ijerph14040438.

[8] Gouli V, Gouli S, Marcelino JAP et al. Entomopathogenic fungi associated with exotic invasive insect pests in northeastern forests of the USA. Insects. 2013;4(4):631-645. doi: 10.3390/insects4040631.

[9] Reid WR, Parker BL, Gouli SY et al. Fungi associated with the hemlock woolly adelgid, Adelges tsugae, and assessment of entomopathogenic isolates for management. Journal of Insect Science. 2010;10(62). 62-64 doi:10.1673/031.010.6201.

[10] Lyamtsev NI, Sergeeva YA, Gninenko YI et al. Priority technologies in forest protection against hazardous organisms. Forestry information. 2019;3:94-108. doi:10.24419/LHI.2304-3083.2019.3.08.

[11] Vityaz SN, Rakina MS, Dyukova EA. (2019). Protection of urban plantings from the Aphrastasia pectinatae chol on the example of the field of the Ábies sibirica and Pínus sylvestris. Presented at: Protection and Rational Use of Forest Resources. Blagoveshchensk - Heihe: Far Eastern State Agriculture University; 2019. June 5-6 Russia, Vladivostok.

[12] Varfolomeeva EA, Mitina GV. Entomopathogenic fungi for control of subtropical plants in the Saint-Petersburg Botanical Garden. Presented at: Modern Technologies and Plant Protection Products - A Platform for Innovative Development in the Agricultural Sector of Russia. FSBSI VIZR; 2018 October 8-12, St.Petersburg, Russia.

[13] De Faria MR, Wraight SP. Mycoinsecticides and mycoacaricides: A comprehensive list with worldwide coverage and international classification of formulation types. Biological Control. 2007;43:237-256. doi.org/10.1016/j.biocontrol.2007.08.001.

[14] Mitina GV, Borisov BA, Pervushin AL et al. Patent for invention RU 2598251 C1, 09/20/2016. Application No. 2015135955/10 of 08.25.2015.

[15] Pavlyushin VA, Mitina GV, Choglokova AA. Laboratory regulations for the production of biologics "Verticillin". St. Petersburg: Innovative Plant Protection Center; 2019. 